\title{
Projections of UV radiation changes in the 21st century: impact of ozone recovery and cloud effects
}

\author{
A. F. Bais ${ }^{1}$, K. Tourpali ${ }^{1}$, A. Kazantzidis ${ }^{2}$, H. Akiyoshi ${ }^{3}$, S. Bekki ${ }^{4}$, P. Braesicke ${ }^{5}$, M. P. Chipperfield ${ }^{6}$, M. Dameris ${ }^{7}$, \\ V. Eyring ${ }^{7}$, H. Garny ${ }^{7}$, D. Iachetti ${ }^{8}$, P. Jöckel ${ }^{7}$, A. Kubin ${ }^{9}$, U. Langematz ${ }^{9}$, E. Mancini ${ }^{8}$, M. Michou ${ }^{10}$,

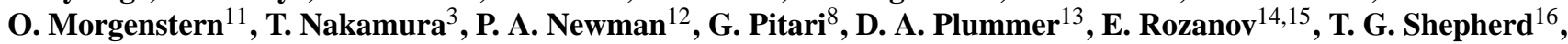 \\ K. Shibata ${ }^{17}$, W. Tian $^{6}$, and Y. Yamashita ${ }^{3}$ \\ ${ }^{1}$ Aristotle University of Thessaloniki, Department of Physics, Thessaloniki, Greece \\ ${ }^{2}$ University of Patras, Department of Physics, Patras, Greece \\ ${ }^{3}$ National Institute for Environmental Studies, Tsukuba, Japan \\ ${ }^{4}$ Service d'Aeronomie, Institut Pierre-Simone Laplace, Paris, France \\ ${ }^{5}$ University of Cambridge, Department of Chemistry, Cambridge, UK \\ ${ }^{6}$ Institute for Climate and Atmospheric Science, University of Leeds, Leeds, UK \\ ${ }^{7}$ Deutsches Zentrum für Luft- und Raumfahrt, Institut für Physik der Atmosphäre, Oberpfaffenhofen, Germany \\ ${ }^{8}$ Università L'Aquila, Dipartimento di Fisica, L'Aquila, Italy \\ ${ }^{9}$ Freie Universität Berlin, Institut für Meteorologie, Berlin, Germany \\ ${ }^{10}$ GAME/CNRM (Météo-France, CNRS), Toulouse, France \\ ${ }^{11}$ National Institute of Water and Atmospheric Research, Lauder, New Zealand \\ ${ }^{12}$ NASA Goddard Space Flight Center, Greenbelt, MD, USA \\ ${ }^{13}$ Environment Canada, Victoria, BC, Canada \\ ${ }^{14}$ Physical-Meteorological Observatory Davos/World Rad. Center, Davos, Switzerland \\ ${ }^{15}$ Institute for Atmospheric and Climate Science ETH, Zurich, Switzerland \\ ${ }^{16}$ Department of Physics, University of Toronto, Toronto, Canada \\ ${ }^{17}$ Meteorological Research Institute, Tsukuba, Japan
}

Received: 7 March 2011 - Published in Atmos. Chem. Phys. Discuss.: 6 April 2011

Revised: 19 July 2011 - Accepted: 20 July 2011 - Published: 1 August 2011

\begin{abstract}
Monthly averaged surface erythemal solar irradiance (UV-Ery) for local noon from 1960 to 2100 has been derived using radiative transfer calculations and projections of ozone, temperature and cloud change from 14 chemistry climate models (CCM), as part of the CCMVal-2 activity of SPARC. Our calculations show the influence of ozone depletion and recovery on erythemal irradiance. In addition, we investigate UV-Ery changes caused by climate change due to increasing greenhouse gas concentrations. The latter include effects of both stratospheric ozone and cloud changes. The derived estimates provide a global picture of the likely changes in erythemal irradiance during the 21 st century. Uncertainties arise from the assumed scenarios, different parameterizations - particularly of cloud effects on UV-Ery - and
\end{abstract}

Correspondence to: A. F. Bais (abais@ auth.gr) the spread in the CCM projections. The calculations suggest that relative to 1980, annually mean UV-Ery in the 2090s will be on average $\sim 12 \%$ lower at high latitudes in both hemispheres, $\sim 3 \%$ lower at mid latitudes, and marginally higher $(\sim 1 \%)$ in the tropics. The largest reduction $(\sim 16 \%)$ is projected for Antarctica in October. Cloud effects are responsible for $2-3 \%$ of the reduction in UV-Ery at high latitudes, but they slightly moderate it at mid-latitudes $(\sim 1 \%)$. The year of return of erythemal irradiance to values of certain milestones (1965 and 1980) depends largely on the return of column ozone to the corresponding levels and is associated with large uncertainties mainly due to the spread of the model projections. The inclusion of cloud effects in the calculations has only a small effect of the return years. At mid and high latitudes, changes in clouds and stratospheric ozone transport by global circulation changes due to greenhouse gases will sustain the erythemal irradiance at levels below those in 1965 , despite the removal of ozone depleting substances.

Published by Copernicus Publications on behalf of the European Geosciences Union. 
At northern high latitudes $\left(60^{\circ}-90^{\circ}\right)$, the projected decreases in cloud transmittance towards the end of the 21 st century will reduce the yearly average surface erythemal irradiance by $\sim 5 \%$ with respect to the $1960 \mathrm{~s}$.

\section{Introduction}

Stratospheric ozone is expected to recover during the coming decades in response to the reduction in ozone depleting substances that have been regulated by the Montreal Protocol and its amendments. However, increases in greenhouse gas (GHG) concentrations are expected to interact with ozone and alter its spatial distribution and its exchange between the stratosphere and the troposphere. These changes in ozone will affect the ultraviolet radiation at the surface. Predictions of future UV radiation levels are important for policy planning, as changes in UV radiation may have both adverse and beneficial effects on humans and ecosystems (UNEP, 2006). Changes in UV radiation in the future will depend on changes in various atmospheric factors, the most important being total ozone, clouds, aerosols, and, at specific locations, surface reflectivity (or albedo). Other factors, such as gaseous pollutants in the troposphere and temperature in the stratosphere, may also play a role (WMO, 2007). Without accounting for the effects of changes in these parameters, Tourpali et al. (2009) estimated the changes in noontime erythemal irradiance based on simulations of total ozone columns and vertical profiles of ozone and temperature from 11 ChemistryClimate Models (CCMs) incorporating stratospheric ozone recovery (Eyring et al., 2007). They estimated decreases in erythemal irradiance of 5-15\% over mid-latitudes between 2000 and 2100, and twice as much at southern high latitudes. These decreases were primarily due to the effects of ozone recovery. Hegglin and Shepherd (2009) calculated changes in the UV Index under clear skies based on ozone fields derived from a CCM and an analytical formulation which was used to estimate the UV Index from ozone and solar zenith angle (Madronich, 2007). By examining the changes between 1965 and 2095, they were able to isolate the effects of climate change from those of ozone depletion and recovery from ozone depleting substances. Over the 1965-2095 period they reported decreases of $9 \%$ in the UV Index in northern high latitudes, increases by $4 \%$ in the tropics, and large increases of up to $20 \%$ in southern high latitudes in late spring and early summer.

In this study we update the results of (Tourpali et al., 2009) using new CCM simulations and parameterizations for the effects of clouds. We discuss the changes in solar erythemal irradiance during the 21 st century calculated with a radiative transfer model using projected ozone, temperature and cloud fields from the most recent CCM simulations carried out for CCMVal-2 (SPARC_CCMVal, 2010) and the "Scientific Assessment of Ozone Depletion: 2010" (WMO, 2011).

\section{Data and methodology}

\subsection{Simulations of erythemal irradiance}

The spectral solar irradiance (flux on a horizontal surface) from 290 to $400 \mathrm{~nm}$ received at Earth's surface is calculated for the entire globe with a radiative transfer (RT) model (libRadtran) (Mayer and Kylling, 2005) based on input data derived from different CCMs, covering the period from 1960 to 2100. In this study we used the REF-B2 and SCN-B2d simulations conducted in the framework of the CCMVal2 activity of SPARC (Eyring et al., 2008; Morgenstern et al., 2010). In these simulations a prescribed scenario for greenhouse gases (SRES A1b) (IPCC, 2001) and the A1 adjusted halogen scenario (WMO, 2007) were used. Compared to the previous model runs under CCMVal-1 (Eyring et al., 2006), most models underwent further development targeting the weaknesses identified in CCMVal-1, providing in general more consistent ozone projections (Austin et al., 2010; Morgenstern et al., 2010). The CCMs used in this study are shown in Table 1 and further details are given in (Morgenstern et al., 2010). We also used results from a simulation of EMAC-FUB model which is a modified version of EMAC with improved representation of polar stratospheric clouds but of lower vertical resolution (39 levels compared to 90 of EMAC).

Simulations of global fields for total ozone and vertical profiles of ozone and air temperature from 14 models have been used, while 5 models provided also the total (shortwave) solar irradiance at the surface under cloud-free and all-sky conditions. For some models projections were available from multiple runs. For these models (including 3 of the models that provided solar irradiance simulations) the ensemble mean of the input parameters was calculated and used in the radiation calculations. As different models provided simulations on different grids, all output data were reduced to a common grid of $5^{\circ} \times 5^{\circ}$.

In addition to the CCM-derived projections, more realistic and spatially variable climatological conditions for the optical depth of aerosols (Kinne et al., 2006) and surface reflectivity (Herman et al., 2001), compared to those of Tourpali et al. (2009), were used in the radiative transfer calculations. As both parameters vary spatially and seasonally, their inclusion in the RT calculations result in longitudinal and seasonal variations of the calculated irradiance fields. These fields were assumed constant throughout the 21st century, although in reality they would likely change as a result of changes in climate. No information on these parameters, usable directly in RT calculations, are included in the available CCM runs. It should be noted that these CCMs did not include realistic representations of tropospheric chemistry, so they do not predict changes in tropospheric ozone which also would be likely to affect surface UV radiation levels in the future. All CCM output parameters were used as monthly averages in the RT model calculations to simulate the spectral 
Table 1. List and basic characteristics of CCMs used in this study. All models provided total ozone, ozone profiles and temperature profiles. Models that provided total radiation under clear and all-sky conditions are checked in the CMF column.

\begin{tabular}{|c|c|c|c|c|c|}
\hline $\mathrm{CCM}$ & $\begin{array}{l}\text { Group and } \\
\text { Location }\end{array}$ & $\begin{array}{l}\text { Horizontal } \\
\text { Resolution }\end{array}$ & $\begin{array}{r}\text { Highest } \\
\text { level }(\mathrm{hPa})\end{array}$ & $\mathrm{CMF}$ & References \\
\hline AMTRAC3 & GFDL, USA & $\sim 200 \mathrm{~km}$ & 0.017 & $\mathrm{X}$ & Austin and Wilson (2010) \\
\hline CAM3.5 & NCAR, USA & $1.9^{\circ} \times 2.5^{\circ}$ & 3.5 & & Lamarque et al. (2008) \\
\hline CCSRNIES & NIES, Tsukuba, Japan & $\mathrm{T} 42$ & 0.012 & & Akiyoshi et al. (2009) \\
\hline CMAM & $\begin{array}{l}\text { EC, University of } \\
\text { Toronto, York Univ., Canada }\end{array}$ & $\mathrm{T} 31$ & 0.00081 & $X$ & $\begin{array}{l}\text { Scinocca et al. (2008); } \\
\text { de Grandpre et al. (2000) }\end{array}$ \\
\hline CNRM-ACM & Meteo-France; France & T63 & 0.07 & & $\begin{array}{l}\text { Deque (2007); } \\
\text { Teyssedre et al. (2007) }\end{array}$ \\
\hline E39CA & DLR, Germany & $\mathrm{T} 30$ & 10 & & $\begin{array}{l}\text { Stenke et al. (2009); } \\
\text { Garny et al. (2009) }\end{array}$ \\
\hline EMAC-FUB & FU Berlin, Germany & $\mathrm{T} 42$ & 0.01 & $\mathrm{X}$ & $\begin{array}{l}\text { Jöckel et al. (2006); } \\
\text { Nissen et al. (2007) }\end{array}$ \\
\hline GEOSCCM & NASA/GSFC, USA & $2^{\circ} \times 2.5^{\circ}$ & 0.015 & & Pawson et al. (2008) \\
\hline LMDZrepro & IPSL, France & $2.5^{\circ} \times 3.75^{\circ}$ & 0.07 & & Jourdain et al. (2008) \\
\hline MRI & MRI, Japan & $\mathrm{T} 42$ & 0.01 & $\mathrm{X}$ & Shibata and Deushi (2008) \\
\hline NIWA-SOCOL & NIWA, NZ & $\mathrm{T} 30$ & 0.01 & & $\begin{array}{l}\text { Schraner et al. (2008); } \\
\text { Egorova et al. (2005) }\end{array}$ \\
\hline SOCOL & $\begin{array}{l}\text { PMOD/WRC and IAC } \\
\text { ETHZ, Switzerland }\end{array}$ & $\mathrm{T} 30$ & 0.01 & $\mathrm{X}$ & $\begin{array}{l}\text { Schraner et al. (2008); } \\
\text { Egorova et al. (2005) }\end{array}$ \\
\hline ULAQ & University of L'Aquila, Italy & $\mathrm{R} 6 / 11.5^{\circ} \times 22.5^{\circ}$ & 0.04 & & $\begin{array}{l}\text { Pitari et al. (2002); } \\
\text { Eyring et al. (2006); } \\
\text { Eyring et al. (2007) }\end{array}$ \\
\hline UMSLIMCAT & University of Leeds, UK & $2.5^{\circ} \times 3.75^{\circ}$ & 0.01 & & $\begin{array}{l}\text { Tian and Chipperfield (2005); } \\
\text { Tian et al. (2006) }\end{array}$ \\
\hline WACCM & NCAR, USA & $1.9^{\circ} \times 2.5^{\circ}$ & $5.9603 \times 10^{-6}$ & & Garcia et al. (2007) \\
\hline
\end{tabular}

irradiance under cloud-free conditions, for the 15th of each month and for local noon (maximum irradiance in a day). For each $5^{\circ} \times 5^{\circ}$ grid, the mean surface elevation was used in the RT calculations derived from the global digital elevation model GTOPO30 (http://www1.gsi.go.jp/geowww/ globalmap-gsi/gtopo30/README.html\#h12). The calculations used in this paper are similar with those presented in Tourpali et al. (2009), but they are based on improved CCM simulations (Eyring, 2008) and on aerosol and surface reflectivity climatologies. An important innovation of this study is the attempt to project UV irradiance in the future with the inclusion of effects from clouds.

For the simulation of solar irradiance at the surface under all-sky conditions, the cloud modification factor (CMF) concept (Staiger et al., 2008) is used. This is a statistical approach that may not be valid for short time scales (minutes or hours). The CMF is defined as the irradiance at the surface under all-sky conditions divided by the irradiance under cloud-free conditions, hence decreasing CMF results in decreasing of irradiance at the surface. By multiplying the irradiance under cloud-free conditions with this factor, the irradiance under all skies is derived. The CMF is wavelength dependent because the effects of clouds on irradiance are wavelength dependent too. The attenuation of total (or short- wave) irradiance by clouds is weaker (about four times less) than that of UV-B irradiance (e.g. Seckmeyer et al., 1996; Blumthaler et al., 1994). However, empirical methods have been developed to convert the CMF for total irradiance to CMF for UV irradiance (e.g. Kazantzidis et al., 2006; Kaurola et al., 2010; den Outer et al., 2005). In this study, the CMF for shortwave irradiance has been derived from cloudfree and all-sky irradiance projections provided by $5 \mathrm{CCMs}$ (AMTRAC, CMAM, MRI, SOCOL, and EMAC-FUB). The radiation schemes used in these models and the methods to parameterize the effects of clouds are discussed in Morgenstern et al. (2010) and in the SPARC CCMVal report (2010, Chapter 3). Shortwave radiation at the surface provided by these models is an approximation, because it is computed from a broad-band RT model designed for radiative heating, and has not been exhaustively evaluated, particularly with respect to the description of clouds (SPARC_CCMVal, 2010, Chapter 3). Therefore the long-term estimates due to changes in the climate system may include large uncertainties, which are then propagated to the UV simulations. However, the CMF calculations depend less on the accuracy of the radiation schemes employed in the CCMs, and more on how clouds and their effects on radiation are represented in each model. This is because the CMF reflects the impact of the 


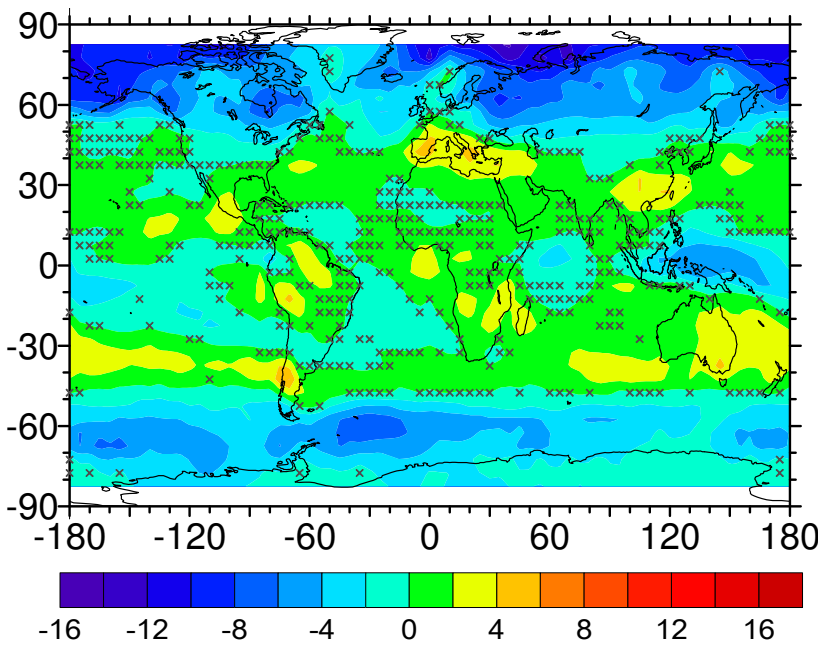

Fig. 1. Multi-model mean changes (\%) in annual mean UV CMF. Changes are given as averages for the period 2090-2099 relative to the period 1960-1969. Crosses mark areas where changes are not statistically significant at the $95 \%$ level.

clouds on surface irradiance under clear skies, irrespective of the absolute values of the calculated irradiance. Any deviations induced from the radiation schemes employed would be the same in clear-sky and all-sky simulations, hence they would cancel out. From the CMFs calculated by the 5 CCMs mentioned above, the multi-model CMF ensemble mean was calculated and used to derive the UV-Ery projections. Although there are differences in the CMFs derived from the 5 models, for all grid points the ensemble mean CMF exceeds the inter-model standard deviation, suggesting consistency in the model estimates.

Figure 1 shows global changes in average UV CMF derived from the 5 models. Changes are given as annual means for the period 2090-2099 relative to 1960-1969. Areas where the calculated changes are not significant at the $95 \%$ confidence level, derived by the t-test of difference between means, are marked with crosses, and indicate higher uncertainty in the estimated CMFs. These results indicate that changes in cloudiness would lead to excess UV radiation (positive changes in CMF) by the end of the 21st century compared to the 1960s. The positive changes are largest in the Mediterranean region and at southern mid-latitudes, particularly over South America and Australia. In contrast, cloudiness is predicted to increase over the high and polar latitudes, particularly in the Northern Hemisphere. These changes are persistent over all seasons (not shown here), though of different magnitude. Moreover, they are consistent with the multi-model projections reported in (IPCC, 2007, Chapter 10) and relate to changes in precipitation due to global warming. The increases in cloudiness lead to decreases in UV radiation, exacerbating the clear-sky changes identified by Hegglin and Shepherd (2009).
From the spectral irradiance simulations the erythemallyweighted solar irradiance (UV-Ery) (McKinlay and Diffey, 1987) was calculated. UV-Ery is a widely used metric to describe the biological effects of UV radiation on human skin and is directly proportional to the UV Index (e.g. McKenzie et al., 2003). This quantity is sensitive to ozone changes, although other weightings (e.g. the DNA damage) are even more sensitive. As cloud effects are also wavelength dependent, the cloud modification factors used here have been derived specifically for erythemal irradiance using the methodology in Kazantzidis et al. (2006).

The above described simulations resulted in a set of time series of monthly erythemal solar irradiance at the surface for the fairly dense grid which covers all Earth's surface for each of the 14 models. To reduce the time and computer power needed for such a large number of simulations, the following simplifications were made:

1. The simulations were performed at a less dense grid from that provided by the CCMs, $10^{\circ}$ in latitude and $10^{\circ}$ in longitude between $60^{\circ} \mathrm{N}$ and $60^{\circ} \mathrm{S}$. At higher latitudes the longitudinal step was increased in inverse proportion to the area of each latitude zone.

2. For the models providing multiple simulations, ensemble mean fields were constructed for all the output parameters. The variations observed among the individual runs were found adequately small, especially when monthly averages were considered.

3. For all grid-points with latitude higher than $60^{\circ}$, the ozone profiles as derived from each CCM and for each month and year were used in the radiation simulations. In all radiation simulations the ozone profile was scaled so that the integrated ozone profile matches the projected total ozone. To reduce computational time, for grid-points between $60^{\circ} \mathrm{N}$ and $60^{\circ} \mathrm{S}$ we used zonally averaged ozone profiles for each model. For the same reason, these profiles were assumed constant throughout the period of the simulations. The validity of this assumption was verified by comparing the average and standard deviation of all profiles in certain time slices for each model and for each latitude belt. A similar concept with the ozone profiles was followed also for the temperature profiles.

4. The cloud modification factors derived from each of the five models were averaged to derive a common but varying with time CMF field, which was then applied to all 14 models. This was done in order to reduce the noise, which is appreciable in the CCM derived cloud effects, and because only a few models provided the data to derive CMFs.

For each grid-point and each model, departures of erythemal irradiance have been computed from the mean over two 
periods, 1960-1969 and 1975-1984, referred in the following as reference years 1965 and 1980 respectively. By this averaging, the large year-to-year variability in the CCM outputs is suppressed, resulting in more representative references. Year 1980 marks the start of the satellite data availability and has been traditionally used as reference for the estimation of changes due to ozone depletion. However, as projected by many CCMs, it is likely that ozone depletion had started well before 1980 (WMO, 2011), hence changes with respect to 1965 have been also calculated and discussed.

\subsection{Uncertainties in projections}

The accuracy of the projections of solar spectral irradiance at the surface is determined mainly by the accuracy in the input parameters (e.g. ozone, aerosols, clouds) used in the RT model (e.g. Weihs and Webb, 1997; Cordero et al., 2007), as for given input parameters the uncertainty of the radiative transfer calculations is small (typically better than 2-5\%) for the RT model (libRadtran) used in this study (see e.g. Mayer and Kylling, 2005 and references therein). The calculation of local noon UV-Ery on the 15th of each month instead of deriving monthly mean UV-Ery from daily values, which was avoided due to limitations in computational time, affects only the level of variability of UV-Ery but has practically no effect on its long term changes. The use of time-independent aerosols and surface albedo throughout the period of the simulations (albeit regionally and seasonally varying) is an additional source of uncertainty. At present, estimates for the time evolution of changes in these parameters are not available, but considering the changes observed during the last 2-3 decades we estimate that the uncertainty that could be introduced in the estimated UV changes should be in the order of a few percent (e.g. Arola et al., 2003). This applies to most locations on earth, except regions where severe climate changes may alter the albedo (e.g. from melting of sea ice, deforestation or desertification) (e.g. Bernhard et al., 2007), or over areas where human activities would severely deteriorate air quality leading to increased amounts of aerosols. In such cases the resultant changes in surface UV radiation can be much greater.

The accuracy of the projected CMF relies on the accuracy of the shortwave radiation estimates provided by the CCMs, particularly when clouds are considered, while the conversion of the CMF for shortwave radiation to UV radiation is much less uncertain (from 3-5 \%) (e.g. den Outer et al., 2005; Lindfors et al., 2007; Kazantzidis et al., 2006). As mentioned already, the representation of clouds in climate models (Dufresne and Bony, 2008) and CCMs is uncertain and depends on the future evolution of GHG emissions. At shorter time scales (e.g. days) the CCM-derived projections related to cloud effects should be much more uncertain. Therefore the use of monthly averaged CMFs is unlikely to increase this uncertainty in the UV-Ery projections particularly as only long term variations in UV-Ery are discussed.
The strong linkages between changes in climate and ozone depletion/recovery are likely to affect the long term trends in ozone amounts as well, by altering relevant chemical and dynamical processes (e.g. Butchart et al., 2010; Engel et al., 2009; McLandress and Shepherd, 2009; SPARC_CCMVal, 2010). The predictions for ozone and radiation used in this study rely on a specific GHG emissions scenario (SRES A1b) and its evolution in the models, therefore a different scenario would result in different ozone amounts for the future. Part of the uncertainties in the UV projections can be attributed to the ozone projections derived by different CCMs. As seen from the spread in the model estimates (see Fig. 2 and relevant discussion) the uncertainty in the ozone projections due to year-to-year variability is rather large, amounting, on average, up to ca. $10 \%$ for the Northern Hemisphere and the tropics and becoming much larger in the Southern Hemisphere (up to ca. $40 \%$ ) (WMO, 2011). The use of monthly averaged ozone to derive monthly UV-Ery instead of monthly averages of UV-Ery calculated from daily ozone projections does not introduce any significant trend in the long term changes in UV-Ery.

All these uncertainties and particularly those implied by the CCM simulations affect the projections of surface erythemal irradiance, at least with respect to the magnitude of the calculated changes, but, presently, they are the best available estimates derived from these models.

\section{Results and discussion}

\subsection{Long term variations in annual mean UV-Ery}

Observations and projections by CCMs suggest that since the late 1990s ozone depletion has stabilized and the ozone layer may have started to recover, although recovery is not yet statistically significant because of natural variability (WMO, 2011). Long-term changes in UV irradiance at the surface are expected to respond to changes in stratospheric ozone, with some modulation caused by changes in clouds. Figure 2 shows changes in UV-Ery under all-sky conditions, relative to the 1975-1985 mean through the end of the 21st century, averaged over five latitude belts: high and mid latitudes of both hemispheres, and tropics. Apart from the tropics, the general pattern is similar in shape with differences occurring in the magnitude of the changes and the degree of inter-model agreement. In all cases, the simulated average change in UV-Ery exhibits a monotonic increase from 1960 towards the end of the 20th century, and reaches a broad maximum during the 2000s. The timing of this maximum is more or less consistent for all models and regions. The change in UV-Ery during the 2000s is dominated by ozone depletion, particularly over the extra-tropical regions. The average increase relative to 1980 is $26 \%$ for the southern high latitudes, and ranges between $3 \%$ and $7 \%$ at other latitude belts, with the smallest change occurring in the tropics. The 


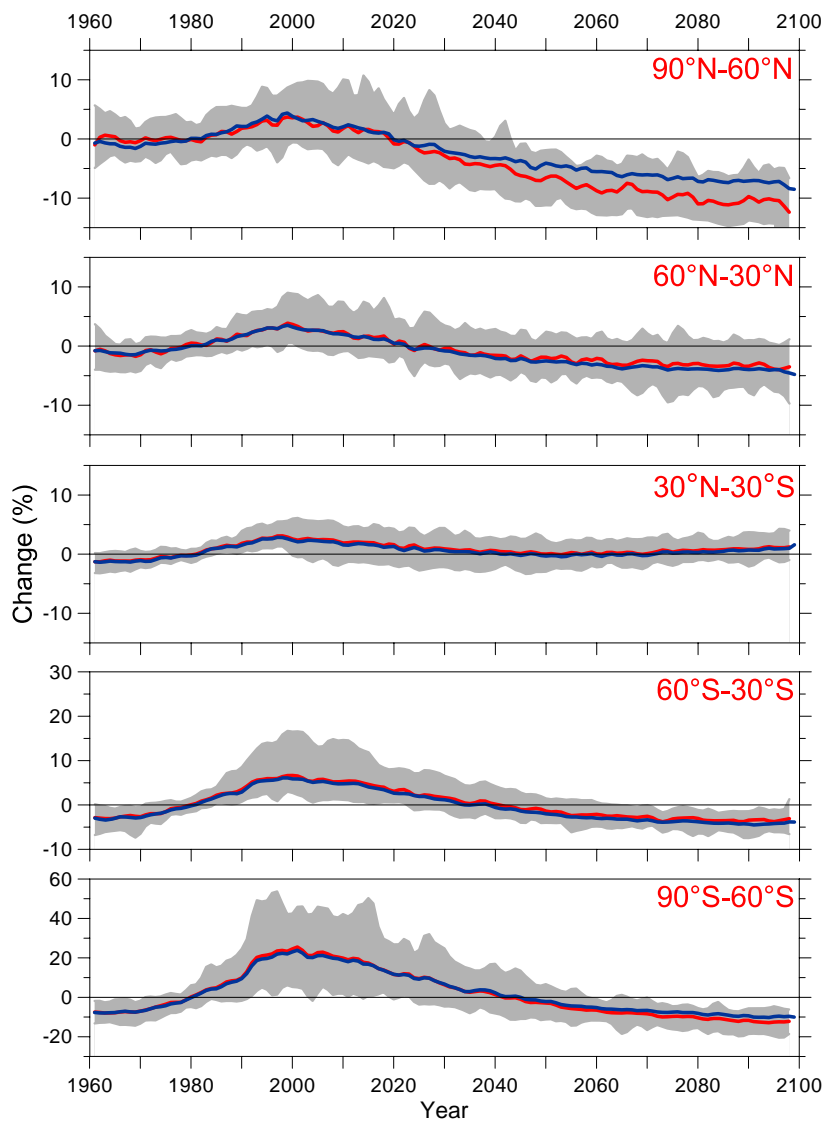

Fig. 2. Annual means of surface erythemal irradiance changes (in $\%$, relative to the 1975-1985 mean) for five latitude bands as indicated in each panel. UV-Ery was calculated with a radiative transfer model using projections of ozone and temperature from $14 \mathrm{CCMs}$ and of clouds from $5 \mathrm{CCMs}$. The red thick line represents the multi model mean and the shaded envelope shows the range of model variations. The blue line represents the multi model mean for cloud free conditions. All lines have been smoothed with a 1:2:1 filter. Note the different scale for the two Southern Hemisphere bands.

same changes, both in magnitude and shape are found also in the clear-sky simulations of UV-Ery, since the projected changes in clouds are small during the first few decades of the period of study.

Between the mid 2000s and the end of the 21st century, changes in UV-Ery decrease steadily, except for the tropics, where a minimum is reached towards the middle of the century followed by a period of increasing tendency. This behaviour is driven by the projected changes in ozone. The continuing decrease in UV after reaching the 1980 levels is also caused by the continuing increase in total ozone. There are two reasons for this behaviour in ozone: first, ozone continues to recover from CFCs towards pre-1980 values. The models predict that ozone depletion had started well before the 1980 benchmark (Shepherd, 2008; WMO, 2011). This effect is significant at least in the Southern Hemisphere. Sec-
Table 2. Multi model mean changes (\%) in clear-sky and all-sky annually averaged erythemal irradiance from 1975-1984 mean to 2090-2099 mean for different regions. Changes in monthly means are shown only for Arctic and Antarctic spring.

\begin{tabular}{lrr}
\hline Region & Clear skies & All skies \\
\hline $90-60^{\circ} \mathrm{N}$ & -7.48 & -10.72 \\
$60-30^{\circ} \mathrm{N}$ & -4.10 & -3.47 \\
$30^{\circ} \mathrm{N}-30^{\circ} \mathrm{S}$ & +0.89 & +1.10 \\
$30-60^{\circ} \mathrm{S}$ & -4.16 & -3.33 \\
$60-90^{\circ} \mathrm{S}$ & -9.80 & -12.39 \\
Arctic April & -6.04 & -11.25 \\
Antarctic October & -12.83 & -15.93 \\
\hline
\end{tabular}

ond, GHGs lead to stratospheric cooling that slows the gasphase ozone depletion in the upper stratosphere and changes the circulation in the lower stratosphere (Shepherd, 2008; Waugh et al., 2009; Li et al., 2009). The circulation change leads to ozone increases at mid and high latitudes and ozone decreases in the tropics. During this period (2000-2100), changes in clouds resulting from climate change are larger, resulting in more pronounced regional effects on solar irradiance at the surface. Particularly over the northern high latitudes, clouds are responsible for an additional average decrease in UV-Ery of ca. $4 \%$. The derived average changes in UV-Ery in 2090-2099 relative to 1980 are summarized in Table 2.

The projected positive trend in UV-Ery over the tropics during the second half of the 21 st century, results also from the negative trend in total ozone due to the intensification of the Brewer-Dobson circulation and strengthening of upwelling (Shepherd, 2008; Butchart et al., 2006), caused by the projected increase in GHGs. The evolution of tropical column ozone depends on the balance between the increase in upper stratospheric concentrations due to the stratospheric cooling and the decrease in lower stratospheric concentrations due to the increase in tropical upwelling through the 21 st century ( $\mathrm{Li}$ et al., 2009). After 2050, column ozone amounts decline slightly again toward the end of the century. Increased tropical upwelling is one of the largest drivers of this (Eyring et al., 2010; Akiyoshi et al., 2010). However, the annually-averaged increase in UV-Ery is small (on average $0.9 \%$, see Table 2) and becomes only slightly larger when clouds are considered. The available cloud projections suggest that local patterns in cloud changes (see Figs. 1 and 4) lead to larger changes in monthly averaged UV-Ery ranging in some areas between $-5 \%$ and $10 \%$. Such additional increases in surface UV radiation by the end of the 21 st century over locations in the tropics, where UV is already high due to the naturally occurring low total ozone columns and the high solar elevation angles, should be considered when assessing risks of adverse effects on the ecosystems in these areas. The effects can be particularly important at high altitude sites in the tropics. 


\subsection{Changes in UV-Ery during the ozone recovery phase}

The most important effect from ozone depletion has been the increase in surface UV-B radiation during the last two decades of the 20th century. Such increases were reported from ground based UV-B radiation measurements at several locations and from satellites, although changes in clouds, aerosols and air quality that occurred during the same period have introduced appreciable noise (den Outer et al., 2010; Bais et al., 2007; Herman, 2010; Fioletov et al., 2001). For the future, an important question is when UV radiation in different regions will return to certain benchmark levels, and whether the long-term changes in clouds will alter these dates. The return year may not be the same at all regions as the long-term variations of ozone and clouds, which are the main drivers for UV radiation, have large spatial variability. The spread in the CCM-derived projections for these factors introduce appreciable uncertainty in the determination of the return year. This spread arises from the year-to-year variability in the model estimates and, to a lesser extent, from differences in the projected speed of recovery of the ozone layer and in the role of the predicted acceleration in the BrewerDobson circulation due to increasing GHGs (e.g. Butchart et al., 2010, 2006; WMO, 2011; SPARC_CCMVal, 2010). Consequently, the return year is determined for the multi model average UV-Ery, while individual models may return at different years. For example, over northern midlatitudes the multi model mean is projected to return to 1980 levels in 2023, while for individual models the return year spans over about two decades before and after 2023 (see Fig. 2).

Table 3 summarizes the return year of average UV-Ery to 1965 and 1980 levels for different regions, both for clearsky and all-sky conditions. Over mid and high latitudes, clear-sky UV-Ery is projected to return to 1980 levels during the first quarter of the 21 st century in the Northern Hemisphere and about $20 \mathrm{yr}$ later in the Southern Hemisphere, in response to the projected ozone changes. For the Northern Hemisphere the same can be said also for its return to 1965 levels. However, in the Southern Hemisphere the return dates of UV-Ery to 1965 levels are delayed by 2-3 decades. In general, the inclusion of cloud effects in the UV simulations has little effect on the return years estimated from the simulations based only on ozone changes, particularly when 1980 is taken as reference. For the southern mid-latitudes, changes in clouds shift the year of return by about $5-7 \mathrm{yr}$.

In Antarctica average clear-sky UV-Ery is projected to return to 1980 by ca. 2050, but it is highly unlikely to return to 1965 levels. This happens only when clouds are included in the model calculations, and all-sky UV-Ery reaches this milestone in ca. 2090. Finally, for the Arctic spring the two milestones are projected to occur about $10 \mathrm{yr}$ later than for the annual mean.

The recovery of the stratospheric ozone layer over the high latitudes of both hemispheres will change significantly the
Table 3. Return years of multi model mean annual erythemal irradiance to its levels in 1965 and 1980, for different regions and for clear- and all-sky conditions. Return years for monthly means are shown only for Arctic and Antarctic spring.

\begin{tabular}{lccccc}
\hline \multirow{2}{*}{ Region } & \multicolumn{2}{c}{1965} & & \multicolumn{2}{c}{1980} \\
\cline { 2 - 3 } \cline { 5 - 6 } & Clear skies & All skies & & Clear skies & All skies \\
\hline $90-60^{\circ} \mathrm{N}$ & 2024 & 2020 & & 2020 & 2019 \\
$60-30^{\circ} \mathrm{N}$ & 2033 & $2033(2035)^{*}$ & & 2023 & 2023 \\
$30^{\circ} \mathrm{N}-30^{\circ} \mathrm{S}$ & - & - & & $2041^{* *}$ & $2048^{* *}$ \\
$30-60^{\circ} \mathrm{S}$ & 2058 & 2065 & & 2039 & 2040 \\
$60-90^{\circ} \mathrm{S}$ & 2071 & 2061 & & 2041 & 2041 \\
Arctic April & 2039 & 2030 & & 2031 & 2024 \\
Antarctic October & - & 2090 & & 2052 & 2050 \\
\hline
\end{tabular}

* At this belt there an ambiguity in the exact determination of the return year. The year in parentheses may be valid as well. ${ }^{* *}$ In the tropics, the return year is ambiguous as changes in UV-Ery approach almost asymptotically the zero line.

UV radiation levels received at the surface. The effect from the return of ozone to its levels in 1980, which is projected to occur everywhere by the mid of the 21 st century, should be reflected in the changes in average clear-sky UV-Ery from 1995-2004 to 2045-2054. Changes in all-sky UV-Ery over the same period would be influenced by changes in clouds too. Global maps of the latter are shown in Fig. 3 for different seasons. Generally the projected changes are negative, with small localized increases in the tropics. Over the tropics the changes are statistically insignificant. Outside the tropics, UV-Ery is projected to decrease by $2-10 \%$ at mid latitudes, and up to $50 \%$ at high latitudes. As expected, the reductions over Antarctica are huge in October, when ozone depletion has been most effective. Large regions with reduced UV-Ery of up to $20 \%$ appear also in the northern high latitudes (e.g. Siberia and Northern Canada) in October and April, attributable mainly to ozone recovery and to a lesser extent (about a quarter of the total reduction) to increases in cloudiness.

\subsection{Effects of climate change on UV-Ery}

Average changes in UV-Ery in 2090-2099 relative to 19601969 mean are caused mainly by climate change, as the two periods are unaffected by ozone depletion or ozone recovery. Thus surface UV is dominated by changes in clouds and changes due to GHGs. Figure 4 shows maps of average UVEry changes under all-sky conditions, for four months. The large spatial variability of changes in clouds modulates the ozone-induced changes and produces localized maxima and minima. Generally, two different regimes can be detected: positive changes occur over the tropics and midlatitudes and negative changes at the high latitudes, during all months. The exception is October in Antarctica where increases in UV-Ery of up to $10 \%$ (ca. $5 \%$ in zonal mean for latitudes $>70^{\circ} \mathrm{S}$ ) are projected, as ozone amounts towards the end of the 21 st century are projected to be lower than in the 1960s. 

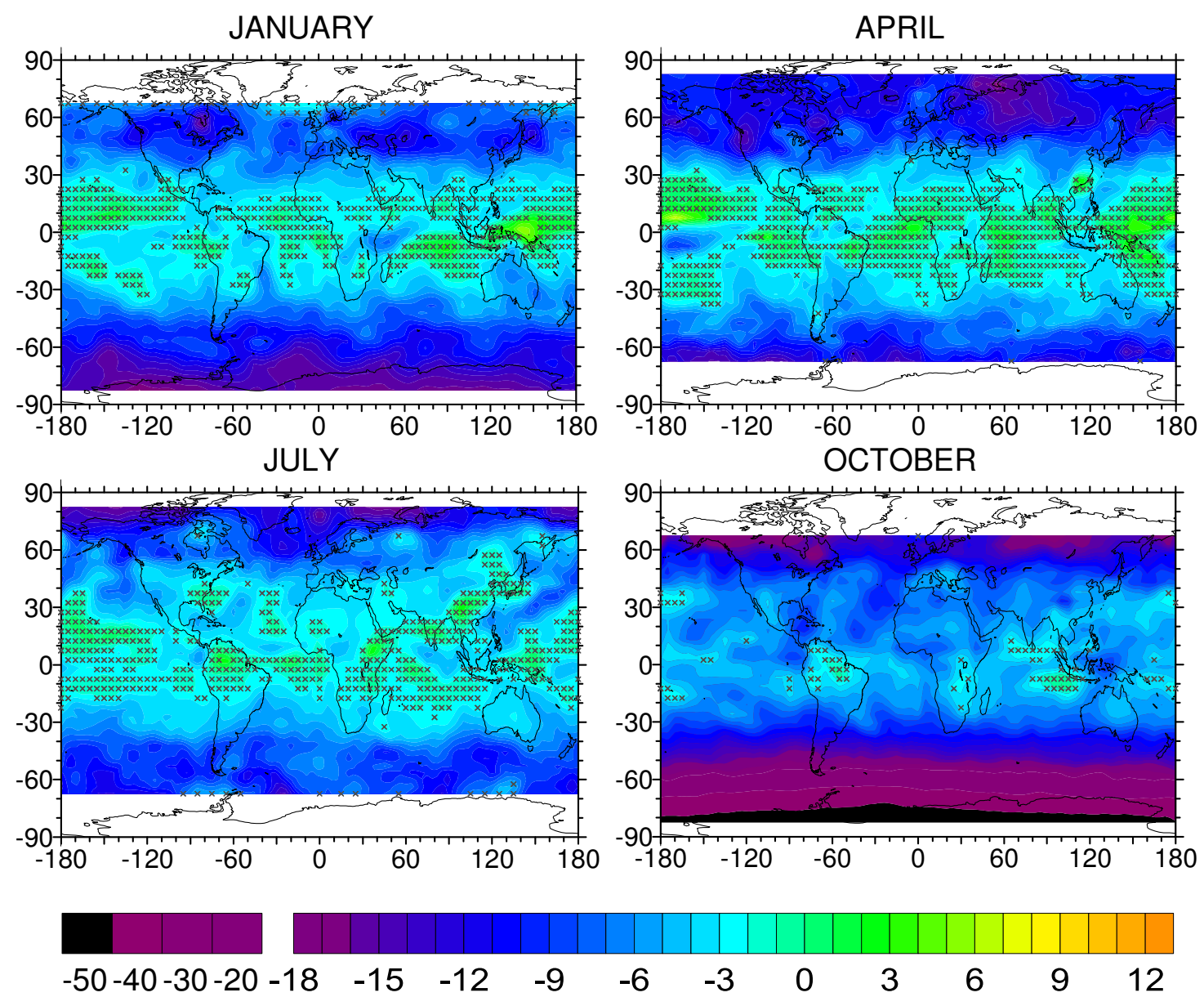

Fig. 3. Multi model mean changes $(\%)$ in UV-Ery under all-sky conditions. Changes are given for monthly means averaged over the period 2045-2054 relative to 1995-2004. Crosses mark areas where changes are not statistically significant at the $95 \%$ level. Note the change in colour scale for reductions larger than $20 \%$.

Increases in the concentration of GHGs during the 21st century would result in strengthening of the polar vortex, hence to lower ozone columns (e.g. Shepherd, 2008; McLandress et al., 2010). Increases in UV-Ery of up to $15 \%$, but for November, were reported by (Hegglin and Shepherd, 2009), using ozone projections from one CCM. These increases would have been ca. 3-5\% smaller if cloud effects were taken into account. Finally, an appreciable dispersion of ca. $15 \%$ is evident in the model estimates (see e.g. Fig. 2) which together with the difference between October and November changes can account for the difference between our results and those of Hegglin and Shepherd (2009).

An important aspect, in terms of the biological effects of changes in UV radiation, is the projected reductions in UVEry over the northern high latitudes, which are more densely populated compared to southern high latitudes. Increases in cloudiness at high latitudes, especially in the cold period in the Arctic, are projected to lead to further reductions in the UV irradiance at the surface, beyond the clear-sky effects identified by Hegglin and Shepherd (2009). While ozone changes are responsible for a decrease of 5-12\%, the changes in clouds produce an additional average decrease of about $5 \%$ over the entire region, and up to $10 \%$ over particular regions (see also Fig. 1). In the Southern Hemisphere midlatitude regions (e.g. the most southern part of South America and southern New Zealand) may experience large UV reductions, all through the year. Such reductions may be important for the population, since maintaining sufficient vitamin D levels in blood is essential for many health aspects (McKenzie et al., 2009; Webb and Engelsen, 2006; UNEP, 2010; Kazantzidis et al., 2009).

The increases in UV-Ery over the mid latitudes and the tropics are generally small and statistically insignificant. However, over specific regions and seasons increases exceeding $10 \%$ have been calculated, attributable mainly to reductions in cloudiness. Most pronounced are the increases over the middle Africa and southern Asia in July, and over some tropical regions in April. 

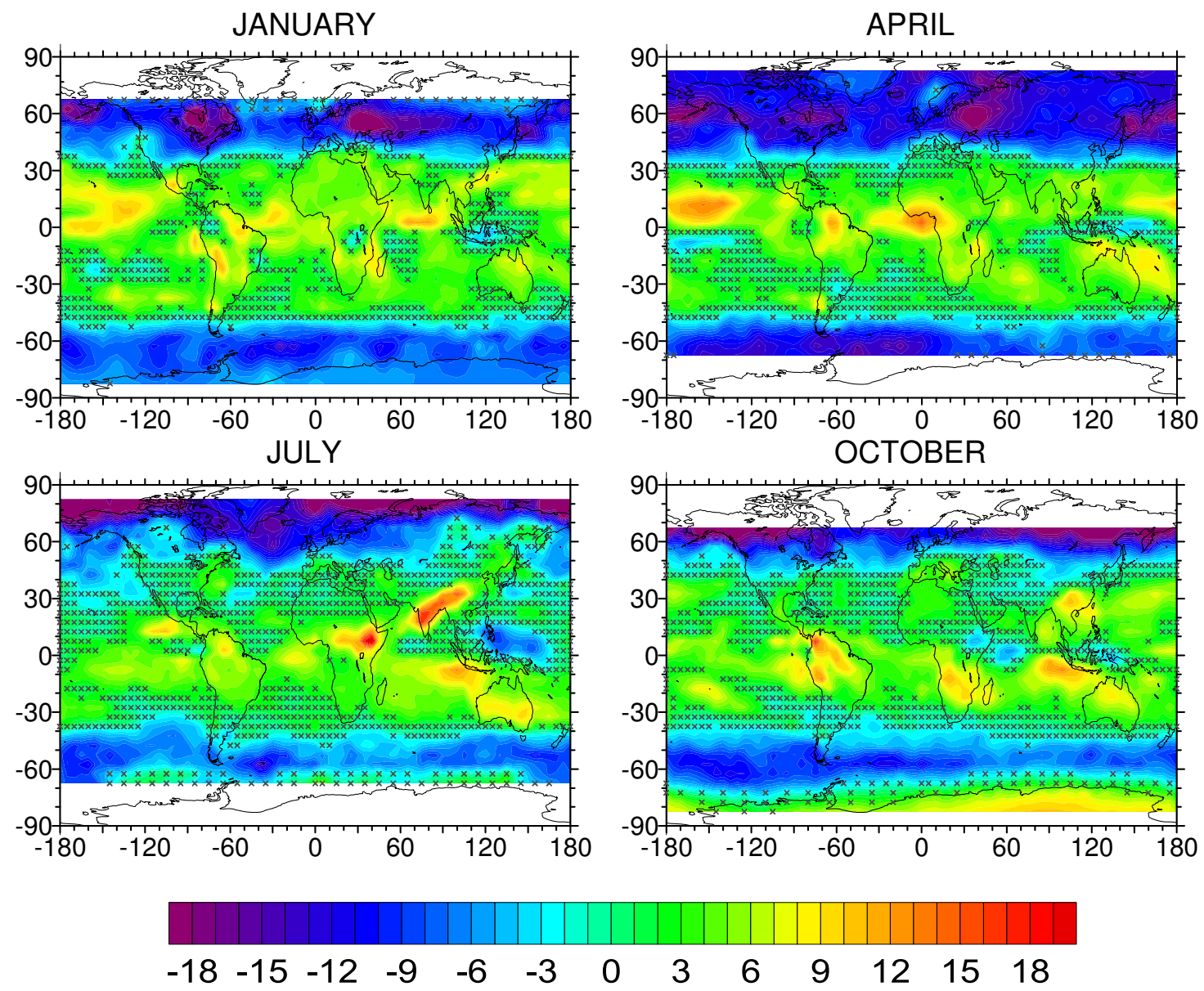

Fig. 4. Multi model mean changes (\%) in UV-Ery under all-sky conditions. Changes are given for monthly means averaged over the period 2090-2099 relative to 1960-1969, reflecting the effect of climate change on UV. Crosses mark areas where changes are not statistically significant at the $95 \%$ level.

An interesting aspect of climate change effect on surface UV radiation over polar regions is the influence of changes in ice and snow cover either in the long term (e.g. Arola et al., 2003) or in the short term (e.g. Meinander et al., 2008; Wuttke et al., 2006). Ice- and snow-covered areas reflect UV radiation back to the atmosphere and a large part of this is redirected downwards through scattering by air molecules and clouds, thereby enhancing the irradiance received at the surface. A decrease in the Arctic sea-ice area during the 21st century (e.g. Overland and Wang, 2007), would thus lead to further reduction in UV-Ery in this area. Over Antarctica, the ozone recovery is projected to result in acceleration of surface warming (Son et al., 2009), which may result in acceleration of ice and/or snow melting and therefore in decreases in surface reflectivity. The net effect will be a reduction of UV irradiance, since both ozone recovery and reduced surface reflectivity would decrease surface UV irradiance.

\section{Conclusions}

Simulations of surface erythemal irradiance for the 21st century reveal large temporal and spatial variations which are caused mainly by changes in total ozone and clouds. This behaviour that was already identified in previous "Scientific Assessment of Ozone Depletion" reports (WMO, 2007, 2003), is quantified based on projections from CMMs. The projected variations in total ozone result in opposite changes in UV-Ery that are modulated by the changes in cloudiness projected for the same period. In the 1980s and 1990s, UV irradiance at Earth's surface exhibited widespread increases as a result of ozone depletion. With the recovery of the ozone layer, which began in the late 1990s, UV-Ery is expected to start decreasing. Whether or when it will return to its historical levels (before the onset of ozone depletion) depends on the timing of the termination of ozone depletion from $\mathrm{CFCs}$, on changes in stratospheric ozone induced by climate change, and also on the evolution of clouds and other tropospheric factors (such as aerosols, surface albedo, and air pollution) in the 21 st century. 
The simulations of this study show that annual mean UVEry will likely return to its 1980 levels by the first quarter of the 21st century in the northern mid and high latitudes, and $20-30 \mathrm{yr}$ later in the southern mid and high latitudes. After reaching this level, simulations show that UV will continue to decrease towards 2100, particularly in the Northern Hemisphere. This behaviour is caused by the continuing increases in total ozone due to circulation changes induced by the increasing GHG concentrations, and at high latitudes is further enhanced by the increases in clouds. In the tropics the UV changes so far have been very small and UV-Ery will continue to be roughly at the 1980 levels or even higher by $2-$ $3 \%$. However, it is highly uncertain whether UV-Ery in the Southern Hemisphere would reach its 1960s levels by 2100 .

Despite the expected recovery of ozone from ozonedepleting substances, UV will probably remain below 1980 or 1960 levels at the end of 21st century due to changes in cloud transmittance and ozone transport due to GHGinduced global circulation changes. Projections by CCMs reveal that cloud transmittance will be lower towards the end of the 21 st century compared to the 1960s, particularly in the Arctic, leading to average reductions in UV-Ery of about $5 \%$, and over particular regions up to $10 \%$. In contrast, at low latitudes the projected changes in clouds will lead to small increases in UV-Ery of a few percent, with some localized increases over continents of more than $10 \%$ during spring and summer.

Radiative transfer models are capable of simulating UV irradiance at the surface quite accurately, given a set of input parameters. The highest uncertainty in the UV calculations is introduced by the uncertainty in simulating these parameters, which also depend strongly on the scenarios assumed for the emissions of greenhouse gases and ozone depleting substances. As it has been discussed already, CCM simulations of ozone and clouds still contain appreciable uncertainties, particularly so far as it concerns clouds. Improvements in parameterisations used in these models would narrow the uncertainties and lead to more certain simulations in the future, both with respect to magnitude and timing of the changes. Even more accurate projections of future UV radiation could be achieved with improved simulations of the evolution of UV influencing factors, such as surface reflectivity, aerosols and gaseous air pollutants, including tropospheric ozone. These factors vary regionally and are strongly linked to changes in climate. Under the currently considered scenarios for the future climate, surface reflectivity will be reduced (sea and land ice melting, reduction in snow cover), while aerosols and air pollutants will likely increase over most of the populated areas, due to human activities. Therefore, the future changes in all these factors will likely lead to reductions in solar UV radiation received at Earth's surface.
Acknowledgements. We acknowledge the Chemistry-Climate Model Validation (CCMVal) Activity for WCRP's (World Climate Research Programme) SPARC (Stratospheric Processes and their Role in Climate) project for organizing and coordinating the model data analysis activity, and the British Atmospheric Data Center (BADC) for collecting and archiving the CCMVal model output. This work has been partly conducted in the framework of the EC Integrated Project SCOUT-O3 (contract 505390-GOCE-CT-2004). CMAM simulations were supported by the Canadian Foundation for Climate and Atmospheric Sciences. U. Langematz would like to thank the German Weather Service who generously provided computer time for the EMAC-FUB simulations. CCSRNIES research was supported by the Global Environmental Research Fund (GERF) of the Ministry of the Environment (MOE) of Japan (A-071 and A-0903) and the simulations were completed with the supercomputer at CGER of the National Institute for Environmental Studies (NIES). We would like to thank the principal investigators of WACCM, AMTRAC, NIWA-Socol, and GEOSCCM models that were used in this study. We are indebted to R. Stolarski for his detailed comments and suggestions.

Edited by: A. Hofzumahaus

\section{References}

Akiyoshi, H., Zhou, L. B., Yamashita, Y., Sakamoto, K., Yoshiki, M., Nagashima, T., Takahashi, M., Kurokawa, J., Takigawa, M., and Imamura, T.: A CCM simulation of the breakup of the Antarctic polar vortex in the years 1980-2004 under the CCMVal scenarios, J. Geophys. Res.-Atmos., 114, D03103, doi:10.1029/2007JD009261, 2009.

Akiyoshi, H., Yamashita, Y., Sakamoto, K., Zhou, L. B., and Imamura, T.: Recovery of stratospheric ozone in calculations by the Center for Climate System Research/National Institute for Environmental Studies chemistry-climate model under the CCMValREF2 scenario and a no-climate-change run, J. Geophys. Res., 115, D19301, doi:19310.11029/12009jd012683, 2010.

Arola, A., Lakkala, K., Bais, A., Kaurola, J., Meleti, C., and Taalas, P.: Factors affecting short- and long-term changes of spectral UV irradiance at two European stations, J. Geophys. Res.-Atmos., 108, 4549, doi:10.1029/2003JD003447, 2003.

Austin, J. and Wilson, R. J.: Sensitivity of polar ozone to sea surface temperatures and halogen amounts, J. Geophys. Res.-Atmos., 115, D18303, doi:10.1029/2009JD013292, 2010.

Austin, J., Scinocca, J., Plummer, D., Oman, L., Waugh, D., Akiyoshi, H., Bekki, S., Braesicke, P., Butchart, N., Chipperfield, M., Cugnet, D., Dameris, M., Dhomse, S., Eyring, V., Frith, S., Garcia, R. R., Garny, H., Gettelman, A., Hardiman, S. C., Kinnison, D., Lamarque, J. F., Mancini, E., Marchand, M., Michou, M., Morgenstern, O., Nakamura, T., Pawson, S., Pitari, G., Pyle, J., Rozanov, E., Shepherd, T. G., Shibata, K., Teyssedre, H., Wilson, R. J., and Yamashita, Y.: Decline and recovery of total column ozone using a multimodel time series analysis, J. Geophys. Res.-Atmos., 115, D00M10, doi:10.1029/2010JD013857, 2010.

Bais, A. F., Lubin, D., Arola, A., Bernhard, G., Blumthaler, M., Chubarova, N., Erlick, C., Gies, H. P., Krotkov, N., Lantz, K., Mayer, B., McKenzie, R. L., Piacentini, R., Seckmeyer, G., Slusser, J. R., and Zerefos, C.: Surface ultraviolet radiation: Past, present and future, Geneva, Switzerland, Chapter 7 in Scientific 
Assessment of Ozone Depletion: 2006, Global Ozone Research and Monitoring Project-Report No. 47, World Meteorological Organization, 58, 2007.

Bernhard, G., Booth, C. R., Ehramjian, J. C., Stone, R., and Dutton, E. G.: Ultraviolet and visible radiation at Barrow, Alaska: Climatology and influencing factors on the basis of version 2 National Science Foundation network data, J. Geophys. Res.-Atmos., 112, D09101, doi:10.1029/2006JD007865, 2007.

Blumthaler, M., Ambach, W., and Salzgeber, M.: Effects of cloudiness on global and diffuse UV irradiance in a high-mountain area, Theor. Appl. Climatol., 50, 23-30, 1994.

Butchart, N., Scaife, A. A., Bourqui, M., de Grandpre, J., Hare, S. H. E., Kettleborough, J., Langematz, U., Manzini, E., Sassi, F., Shibata, K., Shindell, D., and Sigmond, M.: Simulations of anthropogenic change in the strength of the Brewer-Dobson circulation, Clim. Dynam., 27, 727-741, doi:10.1007/s00382-0060162-4, 2006.

Butchart, N., Cionni, I., Eyring, V., Shepherd, T. G., Waugh, D. W., Akiyoshi, H., Austin, J., Bruhl, C., Chipperfield, M. P., Cordero, E., Dameris, M., Deckert, R., Dhomse, S., Frith, S. M., Garcia, R. R., Gettelman, A., Giorgetta, M. A., Kinnison, D. E., Li, F., Mancini, E., McLandress, C., Pawson, S., Pitari, G., Plummer, D. A., Rozanov, E., Sassi, F., Scinocca, J. F., Shibata, K., Steil, B., and Tian, W.: Chemistry-Climate Model Simulations of TwentyFirst Century Stratospheric Climate and Circulation Changes, J. Climate, 23, 5349-5374, doi:10.1175/2010jcli3404.1, 2010.

Cordero, R. R., Seckmeyer, G., Pissulla, D., Dasilva, L., and Labbe, F.: Uncertainty evaluation of the spectral UV irradiance evaluated by using the UVSPEC radiative transfer model, Opt. Commun., 276, 44-53, doi:10.1016/j.optcom.2007.04.008, 2007.

de Grandpre, J., Beagley, S. R., Fomichev, V. I., Griffioen, E., McConnell, J. C., Medvedev, A. S., and Shepherd, T. G.: Ozone climatology using interactive chemistry: Results from the Canadian Middle Atmosphere Model, J. Geophys. Res.-Atmos., 105, 26475-26491, 2000.

den Outer, P. N., Slaper, H., and Tax, R. B.: UV radiation in the Netherlands: Assessing long-term variability and trends in relation to ozone and clouds, J. Geophys. Res.-Atmos., 110, D02203, doi:10.1029/2004JD004824, 2005.

den Outer, P. N., Slaper, H., Kaurola, J., Lindfors, A., Kazantzidis, A., Bais, A. F., Feister, U., Junk, J., Janouch, M., and Josefsson, W.: Reconstructing of erythemal ultraviolet radiation levels in Europe for the past four decades, J. Geophys. Res.-Atmos., 115, D10102, doi:10.11029/12009JD012827, 2010.

Deque, M.: Frequency of precipitation and temperature extremes over France in an anthropogenic scenario: Model results and statistical correction according to observed values, Global Planet. Change, 57, 16-26, doi:10.1016/j.gloplacha.2006.11.030, 2007.

Dufresne, J. L. and Bony, S.: An assessment of the primary sources of spread of global warming estimates from coupled atmosphere-ocean models, J. Climate, 21, 5135-5144, doi:10.1175/2008JCLI2239.1, 2008.

Egorova, T., Rozanov, E., Zubov, V., Manzini, E., Schmutz, W., and Peter, T.: Chemistry-climate model SOCOL: a validation of the present-day climatology, Atmos. Chem. Phys., 5, 1557-1576, doi:10.5194/acp-5-1557-2005, 2005.

Engel, A., Mobius, T., Bonisch, H., Schmidt, U., Heinz, R., Levin, I., Atlas, E., Aoki, S., Nakazawa, T., Sugawara, S., Moore, F., Hurst, D., Elkins, J., Schauffler, S., Andrews, A., and Boering,
K.: Age of stratospheric air unchanged within uncertainties over the past 30 years, Nat. Geosci., 2, 28-31, doi:10.1038/Ngeo388, 2009.

Eyring, V., Butchart, N., Waugh, D. W., Akiyoshi, H., Austin, J., Bekki, S., Bodeker, G. E., Boville, B. A., Brühl, C., Chipperfield, M. P., Cordero, E., Dameris, M., Deushi, M., Fioletov, V. E., Frith, S. M., Garcia, R. R., Gettelman, A., Giorgetta, M. A., Grewe, V., Jourdain, L., Kinnison, D. E., Mancini, E., Manzini, E., Marchand, M., Marsh, D. R., Nagashima, T., Newman, P. A., Nielsen, J. E., Pawson, S., Pitari, G., Plummer, D. A., Rozanov, E., Schraner, M., Shepherd, T. G., Shibata, K., Stolarski, R. S., Struthers, H., Tian, W., and Yoshiki, M.: Assessment of temperature, trace species, and ozone in chemistry-climate model simulations of the recent past, J. Geophys. Res.-Atmos., 111, D22308, doi:10.1029/2006JD007327, 2006.

Eyring, V., Waugh, D. W., Bodeker, G. E., Cordero, E., Akiyoshi, H., Austin, J., Beagley, S. R., Boville, B. A., Braesicke, P., Brühl, C., Butchart, N., Chipperfield, M. P., Dameris, M., Deckert, R., Deushi, M., Frith, S. M., Garcia, R. R., Gettelman, A., Giorgetta, M. A., Kinnison, D. E., Mancini, E., Manzini, E., Marsh, D. R., Matthes, S., Nagashima, T., Newman, P. A., Nielsen, J. E., Pawson, S., Pitari, G., Plummer, D. A., Rozanov, E., Schraner, M., Scinocca, J. F., Semeniuk, K., Shepherd, T. G., Shibata, K., Steil, B., Stolarski, R. S., Tian, W., and Yoshiki, M.: Multi-model projections of stratospheric ozone in the 21 st century, J. Geophys. Res.-Atmos., 112, D16303, doi:10.1029/2006JD008332, 2007.

Eyring, V., Chipperfield, M. P., Giorgetta, M. A., Kinnison, D. E., Manzini, E., Matthes, K., Newman, P. A., Pawson, S., Shepherd, T. G., and Waugh, D. W.: Overview of the New CCMVal Reference and Sensitivity Simulations in Support of Upcoming Ozone and Climate Assessments and the Planned SPARC CCMVal Report, SPARC Newsletter No. 30, 20-26, 2008.

Eyring, V., Cionni, I., Bodeker, G. E., Charlton-Perez, A. J., Kinnison, D. E., Scinocca, J. F., Waugh, D. W., Akiyoshi, H., Bekki, S., Chipperfield, M. P., Dameris, M., Dhomse, S., Frith, S. M., Garny, H., Gettelman, A., Kubin, A., Langematz, U., Mancini, E., Marchand, M., Nakamura, T., Oman, L. D., Pawson, S., Pitari, G., Plummer, D. A., Rozanov, E., Shepherd, T. G., Shibata, K., Tian, W., Braesicke, P., Hardiman, S. C., Lamarque, J. F., Morgenstern, O., Pyle, J. A., Smale, D., and Yamashita, Y.: Multi-model assessment of stratospheric ozone return dates and ozone recovery in CCMVal-2 models, Atmos. Chem. Phys., 10, 9451-9472, doi:10.5194/acp-10-9451-2010, 2010.

Fioletov, V. E., McArthur, L. J. B., Kerr, J. B., and Wardle, D. I.: Long-term variations of UV-B irradiance over Canada estimated from Brewer observations and derived from ozone and pyranometer measurements, J. Geophys. Res.-Atmos., 106, 2300923027, 2001.

Garcia, R. R., Marsh, D. R., Kinnison, D. E., Boville, B. A., and Sassi, F.: Simulation of secular trends in the middle atmosphere, 1950-2003, J. Geophys. Res.-Atmos., 112, D09301, doi:10.1029/2006JD007485, 2007.

Garny, H., Dameris, M., and Stenke, A.: Impact of prescribed SSTs on climatologies and long-term trends in CCM simulations, Atmos. Chem. Phys., 9, 6017-6031, doi:10.5194/acp-9-6017-2009, 2009.

Hegglin, M. I. and Shepherd, T. G.: Large climate-induced changes in ultraviolet index and stratosphere-to-troposphere ozone flux, Nat. Geosci., 2, 687-691, doi:10.1038/Ngeo604, 2009. 
Herman, J. R.: Global increase in UV irradiance during the past 30 years (1979-2008) estimated from satellite data, J. Geophys. Res.-Atmos., 115, D04203, doi:10.1029/2009JD012219, 2010.

Herman, J. R., Larko, D., Celarier, E., and Ziemke, J.: Changes in the Earth's UV reflectivity from the surface, clouds and aerosols, J. Geophys. Res., 106, 5353-5368, 2001.

IPCC: Climate Change 2001: The Scientific Basis. Contribution of Working Group I to the Third Assessment Report of the Intergovernmental Panel on Climate Change., Cambridge, UK, 2001, 4 March 2002, 881 pp., 2001.

IPCC: (Intergovernmental Panel on Climate Change): Climate Change 2007: The Physical Science Basis. Contribution of Working Group I to the Fourth Assessment Report of the Intergovernmental Panel on Climate Change, Cambridge University Press, Cambridge, United Kingdom and New York, NY, USA, Cambridge, UK, and New York, NY, 996, 2007.

Jöckel, P., Tost, H., Pozzer, A., Brhl, C., Buchholz, J., Ganzeveld, L., Hoor, P., Kerkweg, A., Lawrence, M. G., Sander, R., Steil, B., Stiller, G., Tanarhte, M., Taraborrelli, D., van Aardenne, J., and Lelieveld, J.: The atmospheric chemistry general circulation model ECHAM5/MESSy1: consistent simulation of ozone from the surface to the mesosphere, Atmos. Chem. Phys., 6, 50675104, doi:10.5194/acp-6-5067-2006, 2006.

Jourdain, L., Bekki, S., Lott, F., and Lefvre, F.: The coupled chemistry-climate model LMDz-REPROBUS: description and evaluation of a transient simulation of the period 1980-1999, Ann. Geophys., 26, 1391-1413, doi:10.5194/angeo-26-13912008, 2008.

Kaurola, J., Lindfors, A., Lakkala, K., Hansen, G., Josefsson, W., Vuilleumier, L., Feister, U., and Slaper, H.: On the usability of the ERA-40 reanalysis in the estimation of past surface UV radiation over Europe, J. Geophys. Res., 115, D24107, doi:10.1029/2010jd013810, 2010.

Kazantzidis, A., Bais, A., Garane, K., Kazadzis, S., and Meleti, C.: Estimation of UV irradiance from ancillary data and comparison with measurements at Thessaloniki, Greece $\left(40.5^{\circ} \mathrm{N}, 23^{\circ} \mathrm{E}\right), \mathrm{P}$. Soc. Photo-Opt. Ins., Stockholm, Sweden, 2006.

Kazantzidis, A., Bais, A. F., Zempila, M. M., Kazadzis, S., den Outer, P. N., Koskela, T., and Slaper, H.: Calculations of the human vitamin D exposure from UV spectral measurements at three European stations, Photochem. Photobiol. Sci., 8, 45-51, doi:10.1039/b811216a, 2009.

Kinne, S., Schulz, M., Textor, C., Guibert, S., Balkanski, Y., Bauer, S. E., Berntsen, T., Berglen, T. F., Boucher, O., Chin, M., Collins, W., Dentener, F., Diehl, T., Easter, R., Feichter, J., Fillmore, D., Ghan, S., Ginoux, P., Gong, S., Grini, A., Hendricks, J., Herzog, M., Horowitz, L., Isaksen, I., Iversen, T., Kirkevåg, A., Kloster, S., Koch, D., Kristjansson, J. E., Krol, M., Lauer, A., Lamarque, J. F., Lesins, G., Liu, X., Lohmann, U., Montanaro, V., Myhre, G., Penner, J., Pitari, G., Reddy, S., Seland, O., Stier, P., Takemura, T., and Tie, X.: An AeroCom initial assessment - optical properties in aerosol component modules of global models, Atmos. Chem. Phys., 6, 1815-1834, doi:10.5194/acp-6-1815-2006, 2006.

Lamarque, J. F., Kinnison, D. E., Hess, P. G., and Vitt, F. M.: Simulated lower stratospheric trends between 1970 and 2005: Identifying the role of climate and composition changes, J. Geophys. Res.-Atmos., 113, D12301, doi:10.1029/2007JD009277, 2008.

Li, F., Stolarski, R. S., and Newman, P. A.: Stratospheric ozone in the post-CFC era, Atmos. Chem. Phys., 9, 2207-2213, doi:10.5194/acp-9-2207-2009, 2009.

Lindfors, A., Kaurola, J., Arola, A., Koskela, T., Lakkala, K., Josefsson, W., Olseth, J. A., and Johnsen, B.: A method for reconstruction of past UV radiation based on radiative transfer modeling: Applied to four stations in northern Europe, J. Geophys. Res., 112, D23201, doi:10.1029/2007JD008454, 2007.

Madronich, S.: Analytic Formula for the Clear-sky UV Index, Photochem. Photobiol. Sci., 83, 1537-1538, doi:10.1111/j.17511097.2007.00200.x, 2007.

Mayer, B. and Kylling, A.: Technical note: The libRadtran software package for radiative transfer calculations - description and examples of use, Atmos. Chem. Phys., 5, 1855-1877, doi:10.5194/acp-5-1855-2005, 2005.

McKenzie, R. L., Bjorn, L. O., Bais, A., and Ilyas, M.: Changes in biologically active ultraviolet radiation reaching the Earth's surface (Vol. 2, p. 5, 2003), Photochem. Photobiol. Sci., 2, 354 354, 2003.

McKenzie, R. L., Liley, J. B., and Björn, L. O.: UV Radiation: Balancing Risks and Benefits, Photochem. Photobiol. Sci., 85, 88-98, 2009.

McKinlay, A. F. and Diffey, B. L.: A Reference Action Spectrum for Ultra-violet Induced Erythema in Human Skin, in: Human Exposure to Ultraviolet Radiation: Risks and Regulations, edited by: Passchier, W. F. and Bosnajakovic, B. F. M., Elsevier, Amsterdam, 83-87, 1987.

McLandress, C. and Shepherd, T. G.: Simulated Anthropogenic Changes in the Brewer-Dobson Circulation, Including Its Extension to High Latitudes, J. Climate, 22, 1516-1540, doi:10.1175/2008jcli2679.1, 2009.

McLandress, C., Jonsson, A. I., Plummer, D. A., Reader, M. C., Scinocca, J. F., and Shepherd, T. G.: Separating the Dynamical Effects of Climate Change and Ozone Depletion, Part I: Southern Hemisphere Stratosphere, J. Climate, 23, 5002-5020, doi:10.1175/2010jcli3586.1, 2010.

Meinander, O., Kontu, A., Lakkala, K., Heikkil, A., Ylianttila, L., and Toikka, M.: Diurnal variations in the UV albedo of arctic snow, Atmos. Chem. Phys., 8, 6551-6563, doi:10.5194/acp-86551-2008, 2008.

Morgenstern, O., Giorgetta, M. A., Shibata, K., Eyring, V., Waugh, D. W., Shepherd, T. G., Akiyoshi, H., Austin, J., Baumgaertner, A. J. G., Bekki, S., Braesicke, P., Brühl, C., Chipperfield, M. P., Cugnet, D., Dameris, M., Dhomse, S., Frith, S. M., Garny, H., Gettelman, A., Hardiman, S. C., Hegglin, M. I., Jöckel, P., Kinnison, D. E., Lamarque, J. F., Mancini, E., Manzini, E., Marchand, M., Michou, M., Nakamura, T., Nielsen, J. E., Olivié, D., Pitari, G., Plummer, D. A., Rozanov, E., Scinocca, J. F., Smale, D., Teyssèdre, H., Toohey, M., Tian, W., and Yamashita, Y.: Review of the formulation of present-generation stratospheric chemistryclimate models and associated external forcings, J. Geophys. Res.-Atmos., 115, D00M02, doi:10.1029/2009jd013728, 2010.

Nissen, K. M., Matthes, K., Langematz, U., and Mayer, B.: Towards a better representation of the solar cycle in general circulation models, Atmos. Chem. Phys., 7, 5391-5400, doi:10.5194/acp-75391-2007, 2007.

Overland, J. E. and Wang, M.: Future regional Arctic sea ice declines, Geophys. Res. Lett., 34, L17705, doi:10.1029/2007GL030808, 2007.

Pawson, S., Stolarski, R. S., Douglass, A. R., Newman, P. 
A., Nielsen, J. E., Frith, S. H., and Gupta, M. L.: Goddard Earth Observing System Chemistry-Climate Model Simulations of Stratospheric Ozone-Temperature Coupling Between 1950 and 2005, J. Geophys. Res.-Atmos., 113, D12103, doi:10.1029/2007JD009511, 2008.

Pitari, G., Mancini, E., Rizi, V., and Shindell, D.: Impact of future climate and sulfur emission changes on stratospheric aerosols and ozone, J. Atmos. Sci., 59, 414-440, 2002.

Schraner, M., Rozanov, E., Schnadt Poberaj, C., Kenzelmann, P., Fischer, A. M., Zubov, V., Luo, B. P., Hoyle, C. R., Egorova, T., Fueglistaler, S., Brnnimann, S., Schmutz, W., and Peter, T.: Technical Note: Chemistry-climate model SOCOL: version 2.0 with improved transport and chemistry/microphysics schemes, Atmos. Chem. Phys., 8, 5957-5974, doi:10.5194/acp-8-59572008, 2008.

Scinocca, J. F., McFarlane, N. A., Lazare, M., Li, J., and Plummer, D.: Technical Note: The CCCma third generation AGCM and its extension into the middle atmosphere, Atmos. Chem. Phys., 8, 7055-7074, doi:10.5194/acp-8-7055-2008, 2008.

Seckmeyer, G., Erb, R., and Albold, A.: Transmittance of a cloud is wavelength-dependent in the UV- range, Geophys. Res. Lett., 23, 2753-2755, 1996.

Shepherd, T. G.: Dynamics, stratospheric ozone, and climate change, Atmos. Ocean, 46, 117-138, 2008.

Shibata, K. and Deushi, M.: Long-term variations and trends in the simulation of the middle atmosphere 1980-2004 by the chemistry-climate model of the Meteorological Research Institute, Ann. Geophys., 26, 1299-1326, doi:10.5194/angeo-261299-2008, 2008.

Son, S.-W., Tandon, N. F., Polvani, L. M., and Waugh, D. W.: Ozone hole and Southern Hemisphere climate change, Geophys. Res. Lett., 36, L15705, doi:10.1029/2009GL038671, 2009.

SPARC_CCMVal: SPARC Report on the Evaluation of ChemistryClimate Models, Stratospheric Processes And their Role in Climate (SPARC) Report No. 5, WCRP-132, WMO/TDNo. 1526, available: http://www.atmosp.physics.utoronto.ca/ SPARC, edited by: Eyring, V., Shepherd, T. G., and Waugh, D. W., WMO, Geneva, 2010.

Staiger, H., den Outer, P. N., Bais, A. F., Feister, U., Johnsen, B., and Vuilleumier, L.: Hourly resolved cloud modification factors in the ultraviolet, Atmos. Chem. Phys., 8, 2493-2508, doi:10.5194/acp-8-2493-2008, 2008.

Stenke, A., Dameris, M., Grewe, V., and Garny, H.: Implications of Lagrangian transport for simulations with a coupled chemistry-climate model, Atmos. Chem. Phys., 9, 5489-5504, doi:10.5194/acp-9-5489-2009, 2009.

Teyssèdre, H., Michou, M., Clark, H. L., Josse, B., Karcher, F., Olivié, D., Peuch, V.-H., Saint-Martin, D., Cariolle, D., Attié, J.-L., Nédélec, P., Ricaud, P., Thouret, V., van der A, R. J., VolzThomas, A., and Chéroux, F.: A new tropospheric and stratospheric Chemistry and Transport Model MOCAGE-Climat for multi-year studies: evaluation of the present-day climatology and sensitivity to surface processes, Atmos. Chem. Phys., 7, 58155860, doi:10.5194/acp-7-5815-2007, 2007.
Tian, W. and Chipperfield, M. P.: A new coupled chemistry - climate model for the stratosphere: The importance of coupling for future $\mathrm{O}_{3}$-climate predictions, Q. J. Roy. Meteorol. Soc., 131, 281-304, 2005.

Tian, W. S., Chipperfield, M. P., Gray, L. J., and Zawodny, J. M.: Quasi-biennial oscillation and tracer distributions in a coupled chemistry-climate model, J. Geophys. Res.-Atmos., 111, D20301, doi:10.1029/2005JD006871, 2006.

Tourpali, K., Bais, A. F., Kazantzidis, A., Zerefos, C. S., Akiyoshi, H., Austin, J., Brühl, C., Butchart, N., Chipperfield, M. P., Dameris, M., Deushi, M., Eyring, V., Giorgetta, M. A., Kinnison, D. E., Mancini, E., Marsh, D. R., Nagashima, T., Pitari, G., Plummer, D. A., Rozanov, E., Shibata, K., and Tian, W.: Clear sky UV simulations for the 21 st century based on ozone and temperature projections from Chemistry-Climate Models, Atmos. Chem. Phys., 9, 1165-1172, doi:10.5194/acp-9-1165-2009, 2009.

UNEP: Environmental effects of ozone depletion and its interaction with climate change: 2006 assessment, United Nations Environment Programme (UNEP), Nairobi, 206, 2006.

UNEP: Environmental effects of ozone depletion and its interaction with climate change: 2010 assessment, United Nations Environment Programme (UNEP), Nairobi, 278, 2010.

Waugh, D. W., Oman, L., Kawa, S. R., Stolarski, R. S., Pawson, S., Douglass, A. R., Newman, P. A., and Nielsen, J. E.: Impacts of climate change on stratospheric ozone recovery, Geophys. Res. Lett., 36, L03805, doi:10.1029/2008GL036223, 2009.

Webb, A. R. and Engelsen, O.: Calculated ultraviolet exposure levels for a healthy vitamin D status, Photochem. Photobiol. Sci., 82, 1697-1703, 2006.

Weihs, P. and Webb, A. R.: Accuracy of spectral UV model calculations 1. Consideration of uncertainties in input parameters, J. Geophys. Res., 102, 1541-1550, 1997.

WMO: Scientific Assessment of Ozone Depletion: 2002, World Meteorological Organisation, Geneva, Global Ozone Research and Monitoring Project - Report No. 47, 498, 2003.

WMO: (World Meteorological Organization): Scientific Assessment of Ozone Depletion: 2006, World Meteorological Organisation, Geneva, Switzerland Global ozone Research and Monitoring Project - Report No. 50, 572, 2007.

WMO: (World Meteorological Organization): Scientific Assessment of Ozone Depletion: 2010, World Meteorological Organisation, Geneva, Switzerland Global ozone Research and Monitoring Project - Report No. 52, 438, 2011.

Wuttke, S., Seckmeyer, G., and Koenig-Langlo, G.: Measurements of spectral snow albedo at Neumayer, Antarctica, Ann. Geophys., 24, 7-21, doi:10.5194/angeo-24-7-2006, 2006. 